\title{
Causes of Poor Study Habits of Students as Expressed by Primary School Teachers in Nigeria
}

\section{Falilat Anike Okesina}

Department of Counsellor Education, Faculty of Education, University of Ilorin, llorin, Nigeria

$\triangle$ okesina.fa@unilorin.edu.ng

\begin{abstract}
This research investigated the causes of poor study habits of students as expressed by primary school teachers in Nigeria. A descriptive survey design was adopted for this research, and a multi-stage sampling technique procedure was employed to draw a total sample of 200 respondents that participated in the research. The results of the research revealed that the causes of poor study habits of students consisted of poor monitoring by parents, parental educational status and laziness. Moreover, the hypothesis testing conducted in this research stated that there was a significant difference in the causes of poor study habits of students as expressed by teachers based on gender. In addition, there was no significant difference in the causes of poor study habits of students as expressed by teachers based on work experience. Based on the findings of the research, the proposed recommendation is that counselors should be employed in all schools in the country and they should be equipped with supporting facilities to prove their full support and service.
\end{abstract}

Keywords: causes, study habits, primary school, teacher.

How to Cite: Okesina, F. (2019). Causes of Poor Study Habits of Students as Expressed by Primary School Teachers in Nigeria. Mimbar Sekolah Dasar, 6(1), 1-10. doi:http://dx.doi.org/10.17509/mimbarsd.v6il.16413.

INTRODUCTION Education is a key

invention of human being that has been defined in various ways. Research conducted by Isangedighi (2007) viewed education as a tool for self-identity as it began from birth to death. Education is also seen as a tool for national development. To ensure growth in all sectors in any society, the community members must obtain education.

Education is not limited to the school alone, but it could also take place anytime and anywhere. Recently, formal education is increasingly popular in Nigeria. The idea of education as an instrument of change for self and the community/society at large is well received. However, someone has to enroll in the school and excel in academics in order to be considered educated, which can only be realized through studying.

Study habits refer to a habitual dedication to targeted studying. They determine how well a study will progress academically beyond the areas of strength and weakness. It is pertinent that students observe a time-based study on self, and keep studying on time for the purpose of progressing at school. Human beings have varied personality, motivations, ability; when discussing study habits, all of these must be considered. 
Falilat Anike Okesina, Causes of Poor Study Habits of Students...

Reading habits is crucial among students to develop a learning community. It reshapes learner's perception, emotion and behavior. Moreover, it generates innovation and creativity in those who have good study habits (Palani, 2012). Issa et al. (2012) opined that those who studied have high academic achievement. This is corroborated with Sigh (2011) stating that study habits influenced students' academic achievement. A total of 300 randomly sampled high school students expressed that there were differences between the academic achievement and study habits based on gender. Similarly, the study of Bhan and Gupta (2010) on the relationship between students study habits and their academic performance showing that there was no impact of study habits on academic performance based on gender. In another study, Ogbodo (2010) observed high school students who learned at a stipulated time in which the observation revealed there was an increase in reasoning and manipulative abilities and showed that they had great influence on learners' thinking, attitude, growth and development. Based on the aforementioned consideration, this research seeks to focus on causes of poor study habits of students as expressed but secondary schools teachers in order to improve the study habits of students.

\section{Cultural Hindrances to Reading/Study Habits Development of Students in Nigeria}

Individuals' reading behavior is affected by their cultural differences. People tend to have different perceptions of self and their society. African cultures assume overt connectivity among individuals (Jönsson \& Olsson 2008). The culture of the people could interfere with their reading habits. Nigerians are perceived as people who like talking and interacting socially when they are in the company of one another (Sangkaeo, 1999). They prefer listening and chatting to reading. However, there are exceptions in which people prefer to keep to themselves. In this regard, the person could disassociate from social interaction and engage in something meaningful (such as reading).

Some factors that could lead to poor study habits are: (1) Economy Factor: the inability to provide necessary materials to meet the needs of students could culminate into poor study; this is due to lack of materials for reading/studying. Similarly, when there are no food, shelter, clothes etc., it may serve as obstacles to studying. In this instance, a student who do not take breakfast and lunch, due to the parents' inability to serve food, cannot concentrate on learning; (2) Culture of Reading: some Nigerian cultivated the habit of reading with about $40 \%$ of adults who has never read a book after graduating from school. Many Nigerians only read books in order to get a pass when they were in school and as soon as they graduate; they lose interest in reading (Pitan, 2013). Incidentally, parents who are not interested in reading cannot help their child develop good study habits. It is often 
said that children learn from observation. They observe their parents as having poor reading culture, and invariably they develop poor study habits;

Environment: it could be a stumbling block in two ways: (a) moral decay; (b) noise culture. An individual/student who lives in a morally-decayed environment and observe people who do not study getting rich, those who do not study, but successfully passing their examinations may lose interest in studying and shift to anti-social behaviors (Pitan, 2013). They could also engage in examination of malpractice, and bribe the teachers/invigilators to either cheat in the examination hall or pass them when marking. Similarly, there are lots of noises in the Nigerian society (Owoyele, 2012). There is virtually no community in Nigeria that is not noisy. Many schools are even built beside malls and market places. Noise could distract students from studying and cultivating good study habits; (4) Lack of learning materials or facilities: many schools do not have adequate learning facilities, such as library, and relevant books, they are also not allotted time for reading in schools; in addition, lack of motivation from teachers; (5) Improper time management: when students have difficulty in scheduling their study time over other tasks. Many students spend their time for activities that may not add up to their academic success and personal development. For instance, a student spends the whole day on the Facebook, Twitter, or Instagram. Some students also spend their precious time playing games or gambling. These activities do not have any relationship with good academic performance of students. Conversely, they erode away students' precious time that ought to be used for studying. Poor study habits have devastating consequences that could lead to academic failure. Whereas, students need to be responsible in time management to handle their studies.

\section{Statement of the Problems}

There is increasingly high failure of students in external examinations. Initially, the fault was placed on parents, school and government. It has been observed that even though these factors contribute to students' failure, students actually do not have good study habits. Many of them look for easy way out, such as engaging in examination malpractices or bribe their way through rather than study hard.

Many researches on study habits of students abound. For instance, Crede and Kuncel (2008) worked on study habits, skills, and attitudes: These three pillars support collegiate academic performance. Similarly, Pitan (2013) worked on poor study habits as an educational problem among university undergraduates in the contemporary time and effective management strategies, while Gettinger and Seibert (2002) worked on the contributions of study skills to academic competence. In spite of these researches, the study habits of students seem not to improve at all. 
Falilat Anike Okesina, Causes of Poor Study Habits of Students...

There is also no concrete empirical study that shows the depth and seriousness of reading activities, and their impacts on secondary school students. There are reports that reading/study habits has been relegated to the background in our primary schools. The extents to which poor reading/study habits pervade among students have not been determined. In other words, the extent of the prevailing poor study habits among students has not been established yet. The absence of concrete empirical studies to show study frequency profiles of students in Nigeria prompted this research.

\section{Research Questions}

Following are the proposed research questions to address the aforementioned issues:

1. What are the causes of poor study habits of students as expressed by primary school teachers in Nigeria?

2. Is there any difference in the causes of poor study habits of students as expressed by primary school teachers in Nigeria based on gender?

3. Is there any difference in the causes of poor study habits of students as expressed by primary school teachers in Nigeria based on work experience?

\section{Research Hypotheses}

The following null hypotheses were formulated and tested in this research:

1. There is no significant difference in the causes of poor study habits of students as expressed by primary school teachers in Nigeria on the basis of gender.
2. There is no significant difference in causes of poor study habits of students as expressed by primary school teachers in Nigeria on the basis of work experience.

\section{METHODS}

The study employed the use of descriptive survey design. A descriptive survey design aims at fragmenting and delimiting phenomena into measurable or common categories that can be applied to all of the subjects or wider and similar situations (Winter, 2000). The descriptive survey method is appropriate for this research, because it is interested in collecting information from a representative sample on causes of poor study habits of students as expressed by primary school teachers in Nigeria.

The population for this research comprised all elementary school teachers in llorin East Local Government Area, Kwara State, and the target population was primary school teachers, who were drawn from llorin East Local Government Area, Kwara State. simple random sampling technique was used to select two hundred respondents.

The research instrument used for this research was a structured questionnaire developed by the researcher entitled "Causes of Poor Study Habits Questionnaire" (CPSHQ). The instrument contains two sections, namely section A and section B. Section A consists of personal information of the respondents, while section $B$ sought information on causes of poor study habits of students. 
The section contains 20 items and was patterned after4-Likert scale format of Strongly Agree (SA) (4 points), Agree (A) (3 points), Disagree (D) (2 points) and Strongly Disagree (SD) (1 point).

The instrument was administered to five lecturers in the Department of Counsellor Education to ensure its content validity. The test of re-test reliability method was used to test the reliability of the instrument. The scores obtained from the two administrations were subjected to Pearson's Product Moment Correlation Formula and a co-efficient of 0.78 was obtained, which is high enough to use for the study.
The data collected from the instrument were statistically analyzed using descriptive and inferential statistics. Therefore, the demographic data were analyzed using percentages; while data from Section B were analyzed using inferential statistics of t-test and Analysis of Variance (ANOVA). All the hypotheses were tested at 0.05 level of significance.

\section{RESULTS}

Research Question 1: What are causes of poor study habits of students as expressed by primary school teachers in Nigeria?

Table 1. Mean and Rank Order on The Respondents' Expression on Causes of Poor Study Habits.

\begin{tabular}{llll}
\hline Item No. & As far as I am concerned causes of poor study habits is as a result of: & Mean & Rank \\
\hline 1 & poor monitoring by parents & 3.65 & $1^{\text {st }}$ \\
2 & parental educational status & 3.17 & $2^{\text {nd }}$ \\
3 & Laziness & 3.11 & $3^{\text {rd }}$ \\
16 & Stress & 3.10 & $4^{\text {th }}$ \\
9 & Corruption & 3.07 & $5^{\text {th }}$ \\
14 & Attitude & 2.98 & $6^{\text {th }}$ \\
6 & parental socio-economic & 2.97 & $7^{\text {th }}$ \\
19 & learning disability & 2.90 & $8^{\text {th }}$ \\
10 & social media influence & 2.87 & $9^{\text {th }}$ \\
7 & type of school attended & 2.76 & $10^{\text {th }}$ \\
17 & Distraction & 2.75 & $11^{\text {th }}$ \\
11 & lack of motivation & 2.64 & $12^{\text {th }}$ \\
8 & mass media influence & 2.64 & $12^{\text {th }}$ \\
13 & lack of resources & 2.61 & $14^{\text {th }}$ \\
18 & teacher method of teaching & 2.53 & $15^{\text {th }}$ \\
12 & lack of counseling & 2.36 & $16^{\text {th }}$ \\
20 & poor reading upbringing & 2.32 & $17^{\text {th }}$ \\
5 & Environment & 2.29 & $18^{\text {th }}$ \\
15 & disorganized mind & 2.11 & $19^{\text {th }}$ \\
4 & peer group influence & 1.78 & $20^{\text {th }}$ \\
\hline
\end{tabular}

Source: Author's Computation (2018).

Table 1 presents the mean and rank order of respondents' expression of the causes of poor study habits of students. The table indicates that item 1 stating "poor monitoring by parents" ranked 1st with a mean score of 3.65. Item 2 stating "parental educational status" ranked 2nd with a mean score of 3.17. Ranked 3rd is item 3 with a mean score of 3.11 stating "Laziness". On the other hands, item 5 
Falilat Anike Okesina, Causes of Poor Study Habits of Students...

which stating "Environment" ranked 18th with a mean score of 2.29. Item 15 stating "disorganized mind" ranked 19th with a mean score of 2.11, while item 4 stating "peer group influence" ranked 20th with a mean score of 1.78. Since fifteen out of twenty items were above the mid-cut off point of 2.50, then it could be said that respondents attested to the causes of poor study habits among students listed above.

\section{Hypotheses Testing}

Two null hypotheses were postulated and tested. The hypotheses were tested using ttest and ANOVA statistical methods at level of significance of 0.05 .

Hypothesis One: There is no significance difference in the causes of poor study habits of students as expressed by primary school teachers in Nigeria based on gender.

Table 2. Mean, Standard Deviation and T-Value on the Respondents' Expression on the Causes of Poor Study Habits of Students Based on Gender.

\begin{tabular}{|c|c|c|c|c|c|c|c|}
\hline Gender & $\mathrm{N}$ & Mean & SD & $d f$ & Cal. t-value & $\begin{array}{ll}\text { Crit. } & t- \\
\text { value }\end{array}$ & p-value \\
\hline Male & 143 & 53.703 & 4.005 & & & & \\
\hline Female & 57 & 58.000 & 2.272 & 198 & $5.81^{*}$ & 1.96 & .000 \\
\hline
\end{tabular}

$p<0.05$

Source: Author's Computation (2018).

Table 2 shows that the calculated t-value of 5.81 was greater than the critical t-value of 1.96 with corresponding p-value of .000 which was less than 0.05 alpha level. Since the calculated t-value was greater than the critical t-value. Therefore, the hypothesis, which stated that there was a significant difference in the causes of poor study habits among students as expressed by teachers on the basis of gender, was rejected.

Hypothesis Two: There is no significance difference in the causes of poor study habits of students as expressed by primary school teachers in Nigeria based on work experience.

Table 3. Analysis of Variance (ANOVA) on the Respondents' Expression on Causes of Poor Study Habits of Students Based on Work Experience.

\begin{tabular}{lllllll}
\hline Source & SS & df & $\begin{array}{l}\text { Mean } \\
\text { Squares }\end{array}$ & Cal. F-ratio & Crit. F-ratio & p-value \\
\hline Between Groups & 15.274 & 2 & 0.849 & 1.76 & 3.00 & .038 \\
Within Groups & 63.319 & 197 & 0.483 & & & \\
Total & 78.593 & 199 & & & & \\
\hline
\end{tabular}

Source: Author's Computation (2018).

Table 3 shows that calculated F-ratio of 1.76 was less than the critical F-ratio of 3.00 with a corresponding p-value of .038, which was greater than 0.05 alpha level. 
Since the calculated F-ratio was less than the critical F-ratio, the null hypothesis was accepted; there was no significant difference in causes of poor study habits among students as expressed by teachers on the basis of work experience.

\section{DISCUSSION}

The study revealed that the causes of poor study habits of students as expressed by primary school teachers in Nigeria were poor monitoring by parents, parental educational status and laziness. Plowden (2007) whose study showed that the collaboration of teachers and parents would support child's study development for high academic performance. The findings also tally with Nuthanap (2007) revealing that poor study habits of student was caused by poor parental monitoring. The finding of this research concluded that knowledgeable teachers could affect good study habits, hence, they were able to respond along this line.

The findings revealed that there was a significant difference in causes of poor study habits of students as expressed by primary school teachers in Nigeria based on gender. This connotes that the gender of the respondents would influence the causes of poor study habits of students. This research was in line with Sigh (2011) whose findings revealed there was no significant difference on study habits based on gender. Similarly, this research corroborates Bhan and Gputa (2010) showing that gender did not influence study habits and academic achievement.
Similarly, Adegboyega (2018) found that there was no significant difference in the study habits of male and female students.

Another finding revealed that there was no significant difference in causes of poor study habits of students as expressed by primary school teachers in Nigeria based on work experience. It that the work experience of the respondents would not have influence on causes of poor study habits of students. The finding of this research corroborated with Amuda (2007) stating that work experience of respondents did not influence their expressions on study habits. Likewise, the finding was in line with Fabregat and Gupta (2014) in which the findings revealed that there was no significant difference in causes of study habits as perceived by teachers based on work experience.

\section{CONCLUSION}

Based on the aforementioned findings of this research, the following conclusions have been drawn:

The research revealed that causes of poor study habits of students as expressed by primary school teachers in Nigeria were poor monitoring by parents, parental educational status and laziness. Furthermore, there was a significant difference in causes of poor study habits of students as expressed by primary school teachers in Nigeria based on gender, while there was no significant difference in causes of poor study habits of students as 
Falilat Anike Okesina, Causes of Poor Study Habits of Students...

expressed by primary school teachers in

Nigeria on the basis of work experience.

Based on the findings of this research, the proposed recommendations are as follows:

- Counselors should be employed in all schools in the country. They should be supported and equipped with supporting facilities that will help them to perform their best services and performance in the schools especially in handling students with poor study habits.

- Ministry of Education and other related institutions should have programs channeled towards addressing the problems that are faced by teachers in schools who carrying out their duties.

- Students should be properly taught in noise-free environment to allow them to concentrate on the teaching and learning process in the classroom.

- Teachers in schools should consider proper monitoring and mentoring of students in their studies as one of their duties.

- The government should also see to the proper implementation of educational programs in schools for the benefits of the learners, in order to enhance the school quality.

\section{REFERENCES}

Adegboyega, L. O. (2018). Influence of achievement motivation on Nigerian undergraduates' attitude towards examination. International Journal of Instruction, $\quad 11(1), \quad 77-88$. (A
Journal of the Faculty of Education, Eskisehir Osmangazi University, Turkey). Available online at http://www.eiii.net/dosyalar/iii_2018_1_6.pdf

Adeniji, A. J. (2007). A study of junior secondary school students' performance in mathematical signs and symbols. Azare Journal of Education, 6(1), 24-37.

Aluja, A. \& Blanch, A (2004). Socialized personality, scholastic aptitudes, study habits, and academic achievement: Exploring the link. European Journal of Psychological Assessment, 20,

Aina, A. (2012) Lagos Central Library - Past and Present Lagos Librarian 19 pp. 12-13.

Amuda O. (2007) Reading promotion in Nigeria: the role of school Libraries In Elaturoti, David (ed.) Nigerian School Librarianship: Yesterday, Today and Tomorrow. Ibadan: Nigerian School Library Association. pp 173-188.

Anagbogu, M. A. (2002). Guidance and counselling in primary schools. Teacher's handbook. Awka, Nigeria: Macaulay Bright Publishers.

Ayodele, C. S., \& Adebiyi, D. R. (2013). Study Habits as Influence of Academic Performance of Students Nurses of Banquet State University. International Journal of Nursing Science, 5(2), 60-65.

Azikiwe, U. (2008). Study approaches of university students, $\mathrm{WCCl}$ region II forum. (2), Logos, 104-106.

Bajwa, S., \& Jindal, S. (2005). Under Achievement in Science in Relation to Intelligence and Socio-economic Status. Indian Journal of Psychometry and Education, 36(2), 142-145.

Bashir, I., \& Mattoo, N. H. (2012). A Study of Study Habits and Academic Performance Among Adolescents (1419) Years. International Journal of Social Science Tomorrow, 1 (5), 1-8. 
Carew, P. F. C., Hamman - Tukur, A., Fajonyomi, M. G. \& Ali, D. G.

(1994). Study habit patterns and academic performance of university students. Development and testing of SHETI. Salome Psycho Education Service, Maiduguri 10 (4), 22-24.

Crede, M., \& Kuncel, N. R. (2008). Study habits, skills, and attitudes: The third pillar supporting collegiate academic performance. Perspectives on Psychological Science, 3, 425-445.

Fajonyomi, M.G. (1997). Effectiveness of three mode of treatment on anxiety on senior secondary school students. Unpublished PhD Thesis, University of Maiduguri.

Fielden, K. (2014). Evaluating Critical Reflection for Post-graduate

Students in Computing. Informing Science and Information Technology Education (Joint Conference 2005, Flagstaff, Arizona). Retrieved from

http://www.informingscience.org/Proc eedings/In SITE2005/138f36

Field.pdf

Febregat, K. S., \& Gupta, R. (2014). Study Habits and Academic Achievement Among the Students Belonging to SC and None SC Groups. Journal of Applied Research in Education, 15(1), 1-9.

Federal Republic of Nigeria (2004). National Policy on Education. Lagos: Federal Government Press.

Gettinger, M., \& Seibert, J. K. (2002). Contributions of study skills to academic competence. School Psychology Review, 31, 350-365.

Gettinger J. K. \& Seibert M. (2012). A Study of Personality Profiles of Students of Science, Arts and Commerce at Higher Secondary Level of Education in Relation to their Academic Achievement Unpublished Ph.D. Thesis AMU Aligarh, India.

Good, C.V. (2003). Dictionary of education (3rd Edition) New York: Mc Graw Hill Book Company.
Hart, C. \& Keller, E. (2005). The effect of reading and studying skills programme on academic performance and perseverance. Journal of General Education, 29 (2), $89-96$.

Henry, P. (2014) "Children reading habits and their use of media: exhaustive suggestions on encouraging reading habits among children".

Isangedighi, A. J. (2007). A Comparison of Study Habits Among the Under Achieving, the Achieving and Over Achieving Junior Secondary Students. West African Journal of Educational Research, 1, 114-119.

Kagu, B. (2005). Effect of study habit counselling on academic performance of diploma students in University of Maiduguri. In D. M. Gwany, M. G. Fajonyomi, \& B. Kagu, (Ed) Counselling psychology and human resource development. A book of readings in honour of Professor P. F. C. Carew. Ajisafe Press, Lagos. $65-72$.

Nuthanap, P. (2007). Gender analysis of academic achievement among high school students. Unpublished degree of master of home science in human development, thesis. University of Agriculture, Dharwad.

Oguizie, E. \& Agulana, G. G. (2002). Relationship between learning styles to academic achievement on area of specialization of students: Implications for personnel. Journal of Counselling Advancement, 1 (1), 112- 124.

Oluwatimilehin, J. T. B., \& Owoyele, J. W. (2012). Study Habits and Academic Achievement in Core Subjects among Junior Secondary School Students in

Ondo State, Nigeria. Bulgarian Journal of Science and Education Policy, 6(1), 155-169. Retrieved from http://www.bjsep.org

Onweh V.E. (1997) Science and technology education in the past decade in Nigeria: policy, practice and prospects. In: Technology Education in Nigeria. Salami K.A, et al. 
Falilat Anike Okesina, Causes of Poor Study Habits of Students...

(editors). Lagos: Nigerian Association of Teachers of Technology.

Ossai, M. C. (2011). Study habit predicts examination behaviour: An imperative for enhancing quality of college guidance and counselling. Mediterranean Journal of Social Sciences, 2, 23-28.

Ossai, M. C. (2012). Age and Gender Differences in Study Habits: A Framework for Proactive Counselling Against Low Academic Achievement. Journal of Educational and Social Research, 2 (3), $67-73$.

Owoyele, J.W. (2012) Techniques for acquiring study skills. Paper presented at Study Skills Workshop. Tai Solarin University of Education. World Bank World development indicators.

Pitan, O. O. (2013). Poor study habits as an educational problem among university undergraduates in the contemporary time and effective management strategies. International Journal of Humanities and Social Science Invention, 11 (2), 72-76.

Pindar, J. (1999). A comparative study of the effectiveness of client centered and rational emotion. Group counselling models on the study habit of low achieving NCE students in Kashim Ibrahim College of Education, Maiduguri. Unpublished PhD Thesis, University of Maiduguri.

Ramaswamy, R. (1990). Study habit and academic achievement. Journal of Experimental Education, 18 (10), $255-260$.

Plowden, B. (1967). Children and their Primary Schools. A report of the Central Advisory Council for Education (England). London: Her Majesty's Stationary Office.

Sukhwant, B., \& Shalu, J. (2005). Under Achievement in Science in relation to Intelligence and Socioeconomic Status. Indian Journal of Psychometry and Education, 36(2), 142-145. 